\title{
Evaluation on Henan Logistics Efficiency under " The Belt and Road" Initiative
}

\author{
Ping Li \\ School of Management, Zhengzhou University of Industrial Technology; Henan Zhengzhou 451150, China \\ 79146095@qq.com
}

Keywords: DEA, logistics efficiency, efficiency evaluation, Tobit model, "The Belt and Road"

\begin{abstract}
By using the basic model of DEA, the efficiency of logistics input-output data of Henan Province along the Belt and Road from 2004 to 2015 is measured with corresponding analysis given. At the same time, regression analysis of the influencing factors of logistics efficiency is conducted by using Tobit model. The paper concludes that the overall efficiency of logistics industry in Henan Province is high, though lower in the three years; the correlation between government intervention and logistics efficiency is not high, economic development level, marketization degree and industrial structure are important factors affecting logistics efficiency.
\end{abstract}

\section{INTRODUCTION}

In 2013, President Xi Jinping put forward the national strategy of "One Belt, One Road". The regional strategy to optimize regional development pattern and promote coordinated regional development is an important part of the strategy. It is also an important way to solve the imbalance of regional economic and social development and to promote regional economic integration. The key provinces covered by the "One Belt, One Road" strategy are taking this as an opportunity to clearly define their functions, take advantage of their location and characteristics, enhance connectivity, make overall arrangements, rational plan and positive changes to achieve common development. Henan Province has made great efforts and attempts in infrastructure construction, cross-border import and export, and establishment of free trade zone. In particular, the important role of logistics hubs is constantly being strengthened, which is bound to promote economic development.

Modern logistics industry has provided strong support for the optimal allocation of intra-regional and inter-regional resource elements, industrial agglomeration and deep transformation, and enhancement of regional comprehensive competitiveness and sustainable development. Regional logistics has become the key factor in promoting regional rapid economic and social development. Scientific and reasonable efficiency evaluation of regional logistics system is of great practical significance to promote healthy development of regional economy.

In view of this, scholars have carried out a large amount of researches on efficiency evaluation of regional logistics, mostly measurement and analysis of logistics efficiency using the methods of stochastic frontier analysis or data envelopment analysis on the basis of establishing efficiency evaluation system of logistics industry, and reasonable suggestions are proposed accordingly. Ganesh proposed a theoretical framework for evaluating third-party logistics enterprises (Ganesh Vaidyanathan,2005). Hamdan \& Rogers used data envelopment analysis to evaluate the efficiency of third-party logistics (warehousing) operation in the
United States, and revised the evaluation model through analysis(A Hamdan , KJ Rogers,2015). With practitioner number and fixed assets investment in transportation, warehousing and postal industries as input indicators, and added value of the industry as output indicators, Liu Binglian and $\mathrm{Yu}$ Yongze evaluated logistics efficiency of 31 provinces (regions) across the country using DEA model (Binglian Liu, Yongze Yu,2010). On this basis, some scholars introduced energy consumption of the industry into the input indicator, and added two output indicators of various types of freight volume and turnover in further measurement and comparative analysis of regional logistics efficiency (Jianqin Zhang,2013; Xiaobing Le, Ying Wang,2014). Zhong Zuchang and Meng Kui respectively used three-stage DEA method to calculate efficiency of logistic data of 31 provinces in 2007 and six central provinces from 2005 to 2012 by excluding the environment and random factors. (Zuchang Zhong,2010; Kui Meng,2014). From the above studies, we can see that the previous studies mainly evaluated logistics efficiency of large provinces and even all the provinces in China, but few studies individual provinces or regions in the central or western China. This paper uses DEA model to measure logistics efficiency of Henan Province from 2004 to 2015, and carries out Tobit regression analysis of influencing factors in the hope of providing a useful reference for improving logistics industry efficiency in Henan Province. Zhang Jingyi and Zhang Jingcheng pointed out that the overall logistics industry in our country is in a stage characterized by increasing scale efficiency, but the level of operation and management needs to be improved simultaneously (Jingyi Zhang, Jingcheng Zhang,2016). Zhang Xueqing emphasized the synergy between logistics and other industries (Xueqing Zhang,2016), Lian Zhaoda and Cheng Detong took the logistics of 18 provinces along the Belt and Road as the research objects, calculated the overall efficiency of the provinces in 2014 and proposed the strategy for logistics development and adjustment (Zhaoda Lian, Detong Cheng,2017). With One Belt, One Road as background, this paper analyzes the 12-year data of Henan Province in central China, finds out the factors that affect the logistics development in Henan, and puts forward targeted development strategies. 


\section{DEA MODEL}

\section{$2.1 C^{2} R$ model}

Proposed by American Charnes, Cooper and Rhodes in 1978, the model was to evaluate relative efficiency of systemic analysis method. The $\mathrm{C}^{2} \mathrm{R}$ model is based on the principle of constant returns to scale. The general form of its input-oriented model is:

$$
\left\{\begin{aligned}
& \mathrm{m} \text { in } \theta-\varepsilon\left(\hat{e}^{T} s^{-}+e^{T} s^{+}\right), \\
& \text {s.t. } \sum_{j=1}^{n} x_{j} \lambda_{j}+s^{-}=\theta x_{0}, \\
& \sum_{j=1}^{n} y_{j} \lambda_{j}-s^{+}=y_{0}, \\
& \lambda_{j} \geq 0, j=1,2, \cdots, n, \\
& s^{-} \geq 0, s^{+} \geq 0 .
\end{aligned}\right.
$$

\subsection{BC2 model}

Due to the comprehensive factors of economic environment, it is difficult for DMU to ensure existence of such an ideal and unaffected scale. On the contrary, to achieve the best scale, scale will have an impact on scale efficiency. Therefore, Banker, Charnes and Cooper proposed BC2 model in 1984, which assumes a variable scale return and contains Archimedes infinite $\varepsilon$ and slack variables $S^{-}, S^{+}$(Zhanxin Ma,2016). The general form of its input-oriented model is:

$$
\begin{cases}\max & \delta-\varepsilon\left(\hat{e}^{T} s^{-}+e^{T} s^{+}\right), \\ \text {s.t. } & \sum_{j=1}^{n} x_{j} \lambda_{j}+s^{-}=\delta x_{0}, \\ & \sum_{j=1}^{n} y_{j} \lambda_{j}-s^{+}=y_{0}, \\ & \sum_{j=1}^{n} \lambda_{j}=1, \\ & \lambda_{j} \geq 0, j=1,2, \cdots, n, \\ & s^{-} \geq 0, s^{+} \geq 0 .\end{cases}
$$

The $\delta$ value measured by the $\mathrm{BC}^{2}$ model is the pure technical efficiency PTE value, which indicates the use efficiency of input resources. From $\mathrm{C}^{2} \mathrm{R}$ and $\mathrm{BC}^{2}$ models, scale efficiency SE = TE / PTE can be obtained through calculation to determine whether the combination between input and output terms of each DMU reaches the optimal scale state.

\subsection{Super efficiency model}

Super-efficiency DEA model was first proposed by P. Andersen and N. C. Petersen in 1993. The model mainly solves the problem of incapability to distinguish efficiency difference due to numerous effective units of the previous model. The dual form of $C^{2} \mathrm{R}$ improvementbased super-efficiency model is:

$$
\begin{cases}\min & \eta-\varepsilon\left(\hat{e}^{T} s^{-}+e^{T} s^{+}\right), \\ \text {s.t. } & \sum_{j=1}^{n} x_{j} \lambda_{j}+s^{-}=\eta x_{k}, \\ & \sum_{\substack{j=1 \\ j \neq k}}^{n} y_{j} \lambda_{j}-s^{+}=y_{k}, \\ & \lambda_{j} \geq 0, j=1,2, \cdots, n, \\ & s^{-} \geq 0, s^{+} \geq 0 .\end{cases}
$$

\begin{tabular}{|c|c|c|c|}
\hline $\begin{array}{c}\text { Indicator } \\
\text { type }\end{array}$ & Indicator name & Indicator unit & Indicator explanation \\
\hline \multirow{3}{*}{$\begin{array}{c}\text { Input } \\
\text { indicators }\end{array}$} & $\begin{array}{l}\text { practitioner number of } \\
\text { transportation, warehousing } \\
\text { and postal industries(X1) }\end{array}$ & 10 thousand & $\begin{array}{c}\text { It represents the level } \\
\text { of industry } \\
\text { practitioners and } \\
\text { human resources } \\
\text { investment }\end{array}$ \\
\hline & $\begin{array}{l}\text { fixed assets investment of } \\
\text { transportation, warehousing } \\
\text { and postal industries (X2) }\end{array}$ & $\begin{array}{l}100 \text { million } \\
\text { RMB }\end{array}$ & $\begin{array}{c}\text { It represents the } \\
\text { industry's capital } \\
\text { investment volume } \\
\end{array}$ \\
\hline & $\begin{array}{l}\text { energy consumption of } \\
\text { transportation, warehousing } \\
\text { and postal industries (X3) }\end{array}$ & $\begin{array}{c}\text { Ten thousand } \\
\text { tons of } \\
\text { standard coal }\end{array}$ & $\begin{array}{c}\text { Industry infrastructure } \\
\text { and resources } \\
\text { investment }\end{array}$ \\
\hline \multirow{3}{*}{$\begin{array}{c}\text { Output } \\
\text { indicators }\end{array}$} & $\begin{array}{c}\text { output value of } \\
\text { transportation, warehousing } \\
\text { and postal industries (Y1) }\end{array}$ & $\begin{array}{l}100 \text { million } \\
\text { RMB }\end{array}$ & \begin{tabular}{|c|} 
It reflects scale and \\
development level of \\
logistics industry
\end{tabular} \\
\hline & freight volume (Y2) & $\begin{array}{l}10 \text { thousand } \\
\text { tons }\end{array}$ & $\begin{array}{l}\text { It refers to the total } \\
\text { cargo transportation } \\
\text { volume of logistics } \\
\text { industry, an indicator } \\
\text { of transport capacity }\end{array}$ \\
\hline & freight turnover (Y3) & $\begin{array}{l}100 \text { million } \\
\text { tons/km }\end{array}$ & $\begin{array}{l}\text { It refers to the product } \\
\text { of freight volume and } \\
\text { freight distance in a } \\
\text { specific time, and } \\
\text { reflects the transport } \\
\text { capacity to some } \\
\text { extent }\end{array}$ \\
\hline
\end{tabular}

\section{EVALUATION OF HENAN LOGISTICS EFFICIENCY UNDER THE BACKGROUND OF ONE BELT, ONE ROAD}

\subsection{Establishment of evaluation system}

At home and abroad, scholars have no unified definition for the scope of logistics industry. In the actual statistics of each year in our country, the output value of transportation, warehousing and postal industries accounts for more than $85 \%$ of the total added value of the logistics industry. Therefore, this paper defines the scope of the research object, logistics industry, as transportation, warehousing and postal industries.

Table 1: Henan Logistics Efficiency Evaluation System

Based on the definition of logistics industry and the application of DEA method, fixed assets investment, energy consumption, practitioner number of transportation, warehousing and postal industries are selected as input indicators, output value, freight volume, freight turnover of transportation, warehousing and postal industries are selected as output indicators from the perspectives of manpower, material and financial resources according to actual situation of the industry. Then, evaluation system of Henan logistics efficiency is built on this basis, as shown in Table 1. 


\subsection{Data collection and reduction}

When using DEA model to measure the efficiency, we can evaluate logistics efficiency of different regions in the same period or different periods, and also measure the efficiency of the same area in different periods. This paper treats each year of 2004-2015 as a decisionmaking unit (DMU) to evaluate the logistics efficiency in Henan Province vertically.
For the input and output indicators, practitioner number, fixed assets investment, energy consumption, output value of logistics industry, freight volume and freight turnover can be acquired from "Statistical Yearbook of Henan Province" and "China Energy Statistical Yearbook" of 2003-2016. After collecting and organizing the relevant data, the logistics input-output data of Henan Province from 2004 to 2015 are obtained as shown in Table 2.

Table 2: Logistics input-output data sheet of Henan Province from 2004 to 2015

\begin{tabular}{|c|c|c|c|c|c|c|}
\hline Year & $\begin{array}{c}\text { practitioner } \\
\text { number }\end{array}$ & $\begin{array}{c}\text { fixed assets } \\
\text { investment }\end{array}$ & $\begin{array}{c}\text { energy } \\
\text { consump } \\
\text { tion }\end{array}$ & $\begin{array}{c}\text { output } \\
\text { value of } \\
\text { logistics } \\
\text { industry }\end{array}$ & $\begin{array}{c}\text { freight } \\
\text { volume }\end{array}$ & $\begin{array}{c}\text { freight } \\
\text { turnover }\end{array}$ \\
\hline 2004 & 180.37 & 415.01 & 566.11 & 678.73 & 73264 & 2107.26 \\
\hline 2005 & 187.29 & 541.43 & 649.93 & 625.87 & 78827 & 2282.6 \\
\hline 2006 & 188.9 & 696.68 & 673.04 & 739.29 & 86608 & 2415.89 \\
\hline 2007 & 198.7 & 508.38 & 772.28 & 866.73 & 101410 & 2729.3 \\
\hline 2008 & 204.46 & 485.48 & 802.43 & 802.25 & 138392 & 5215.84 \\
\hline 2009 & 207.69 & 583.89 & 875.72 & 823.57 & 169643 & 6146.09 \\
\hline 2010 & 213.14 & 791.54 & 1340.6 & 873.3 & 202470 & 7141.82 \\
\hline 2011 & 217.8 & 812.54 & 1288.68 & 961.5 & 240965 & 8471.07 \\
\hline 2012 & 222.77 & 927.25 & 1418.56 & 1151.91 & 272240 & 9436.42 \\
\hline 2013 & 242.8 & 1201.45 & 1467.14 & 1309.3 & 304369 & 7205.05 \\
\hline 2014 & 234.71 & 1391.7 & 1487.58 & 1676.46 & 200626 & 7367.09 \\
\hline 2015 & 242.84 & 1937.81 & 1602.82 & 1809.39 & 211854 & 7582.28 \\
\hline
\end{tabular}

\subsection{DEA effectiveness analysis of logistics efficiency}

In this paper, DEA Solver Pro 5.0 software is used to calculate the efficiency of C2R, BC2 and Super-C2R models for the data in Table 2, obtaining technical

Table3: Table of Henan Logistics Efficiency Evaluation Results

\begin{tabular}{|c|c|c|c|c|c|c|}
\hline DMU & $\begin{array}{c}\text { overall } \\
\text { efficiency }\end{array}$ & $\begin{array}{l}\text { pure technical } \\
\text { efficiency }\end{array}$ & $\begin{array}{c}\text { Scale } \\
\text { efficiency }\end{array}$ & $\begin{array}{c}\text { Super } \\
\text { efficiency }\end{array}$ & $\begin{array}{c}\text { Super } \\
\text { efficiency } \\
\text { return }\end{array}$ & $\begin{array}{l}\text { Returns to } \\
\text { scale }\end{array}$ \\
\hline $\begin{array}{l}\text { Year } \\
2004\end{array}$ & 1.000 & 1.000 & 1.000 & 1.067 & 6 & invariant \\
\hline $\begin{array}{l}\text { Year } \\
2005\end{array}$ & 0.844 & 0.969 & 0.871 & 0.844 & 12 & Increasing \\
\hline $\begin{array}{l}\text { Year } \\
2006\end{array}$ & 0.944 & 0.976 & 0.967 & 0.944 & 10 & Increasing \\
\hline $\begin{array}{l}\text { Year } \\
2007\end{array}$ & 1.000 & 1.000 & 1.000 & 1.072 & 5 & invariant \\
\hline $\begin{array}{l}\text { Year } \\
2008\end{array}$ & 1.000 & 1.000 & 1.000 & 1.126 & 2 & invariant \\
\hline $\begin{array}{l}\text { Year } \\
2009\end{array}$ & 1.000 & 1.000 & 1.000 & 1.064 & 7 & invariant \\
\hline $\begin{array}{l}\text { Year } \\
2010\end{array}$ & 0.874 & 0.983 & 0.889 & 0.874 & 11 & Increasing \\
\hline $\begin{array}{l}\text { Year } \\
2011\end{array}$ & 1.000 & 1.000 & 1.000 & 1.016 & 9 & Invariant \\
\hline $\begin{array}{l}\text { Year } \\
2012\end{array}$ & 1.000 & 1.000 & 1.000 & 1.113 & 3 & invariant \\
\hline $\begin{array}{l}\text { Year } \\
2013\end{array}$ & 1.000 & 1.000 & 1.000 & 1.080 & 4 & invariant \\
\hline $\begin{array}{l}\text { Year } \\
2014\end{array}$ & 1.000 & 1.000 & 1.000 & 1.139 & 1 & invariant \\
\hline $\begin{array}{l}\text { Year } \\
2015\end{array}$ & 1.000 & 1.000 & 1.000 & 1.043 & 8 & invariant \\
\hline $\begin{array}{l}\text { Mean } \\
\text { value }\end{array}$ & 0.972 & 0.994 & 0.977 & 1.032 & & \\
\hline
\end{tabular}

As can be known from overall efficiency in Table 3, technical efficiency of years 2004, 2007, 2008, 2009, 2011, 2012, 2013, 2014 and 2015 are1, indicating that Henan logistics efficiency achieves optimal state in these efficiency value, pure technical efficiency value and scale efficiency value (division of the former two) and super efficiency values of logistics efficiency. The specific operation results are shown in Table 3 below. years. Efficiency values in 2005, 2006 and 2010 are less than 1, indicating invalid DEA efficiency in the three years when there is no inadequate, reasonable logistics resource and the best input-output status is not achieved. 
In the same way, pure technical efficiency and scale efficiency also exhibit the same characteristics as technical efficiency. Certainly, technical efficiency of less than 1 is due to the simultaneous invalidation of scale efficiency and pure technical efficiency in these years. By combining changes in returns to scale, we can see that returns to scale are on the rise during the years with invalid DEA, indicating that logistics scale in Henan Province is small in these years and the optimal production scale is not reached. Therefore, for these years with irrational resource allocation and small scale, utilization rate of human, financial and material resources should be increased, and logistics production scale should be appropriately enlarged to ultimately increase logistics efficiency. In overall, the average efficiency of Henan logistics industry is 0.972, the average pure technical efficiency is 0.994, the average scale efficiency is 0.977 , and the logistics industry as a whole is in invariant or increasing stage, indicating that the overall efficiency of logistics industry is at a high level.

From the super efficiency point of view, efficiency value is the highest in 2014, followed by that in 2008, indicating that Henan logistics industry scale achieves the optimal scale in these two years, also, resource allocation and management level reaches the optimal state. The efficiency value is the lowest in 2005, followed by that in 2010. In these years with invalid technical efficiency, inefficiency is caused by input redundancy or under-production. The specific excess and shortage are shown in Table 4.

Table 4: Input redundancy and under-production table

\begin{tabular}{|c|c|c|c|c|c|c|c|}
\hline & & Excess & Excess & Excess & Shortage & Shortage & Shortage \\
\hline DMU & Score & Practitioner number & $\begin{array}{c}\text { Fixed assets } \\
\text { investment }\end{array}$ & $\begin{array}{c}\text { Energy } \\
\text { consumption } \\
\text { equivalent }\end{array}$ & $\begin{array}{c}\text { Output value of } \\
\text { logistics } \\
\text { industry }\end{array}$ & $\begin{array}{c}\text { Freight } \\
\text { volume }\end{array}$ & $\begin{array}{c}\text { Freight } \\
\text { turnover }\end{array}$ \\
\hline $\begin{array}{c}\text { Year } \\
2005\end{array}$ & 0.847 & S-(1) & S-(2) & S-(3) & S+(1) & S+(2) & S+(3) \\
\hline $\begin{array}{c}\text { Year } \\
2006\end{array}$ & 0.959 & 0 & 47.728 & 0 & 0 & 0 & 134.310 \\
\hline $\begin{array}{c}\text { Year } \\
2010\end{array}$ & 0.874 & 0 & 166.782 & 0 & 0 & 0 & 0 \\
\hline
\end{tabular}

In 2005 and 2006, the fixed assets investment had a redundancy of 0.47728 million yuan and 16.6782 billion yuan respectively; while in 2005, the freight turnover needed to be increased by 13.431 billion tons/ km to achieve the best efficiency; in 2005, energy consumption of 0.90079 million tons of standard coal needed to be reduced, and freight volume of 7.09289 million tons needed to be increased to achieve the best production frontier of all years and make DEA effective.

\subsection{Determination of influencing factors and Tobit regression analysis}

Combining the related literatures and the industry reality, three input indicators of logistics efficiency are excluded, and four exogenous influencing factors of Henan Province's economic development level, degree of marketization, government intervention and industrial structure are finally selected as independent variables. With technical efficiency of logistics as dependent variable, Tobit model is constructed (the dependent variable is truncated in the value domain for applicability), and regression analysis is conducted to determine how each independent variable affects technical efficiency of the logistics industry.

\subsubsection{Tobit model construction}

According to data availability and scientificity principle, in this paper, the total amount of Henan GDP, marketization index, proportion of fiscal expenditure in the provincial GDP and proportion of secondary industry added value in the provincial GDP respectively represent economic development level, marketization degree, government intervention and industrial structure of Henan Province. The data is selected from 2005-2016
"Statistical Yearbook of Henan Province," and the constructed Tobit regression model is:

$$
\mathrm{Y}_{\mathrm{i}}=\beta_{0}+\beta_{1} \mathrm{GDP}_{\mathrm{i}}+\beta_{2} \mathrm{M}_{\mathrm{i}}+\beta_{3} \operatorname{Gov}_{\mathrm{i}}+\beta_{4} \mathrm{IS}_{\mathrm{i}}+\mu
$$

In equation (4), $\beta 0$ represents the constant term; $\beta 1$, $\beta 2, \beta 3, \beta 4$ responses represent the regression coefficients of the four explanatory variables; i represents the period ( $i=2004,2001 \ldots, 2015) ; \mu$ represents the error term of the regression equation; Yi indicates technical efficiency of logistics; GDP i, Mi, Gov i and IS i respectively represent GDP, marketization index, government intervention degree and proportion of secondary industry added value in GDP of Henan Province in period $\mathrm{i}$

\subsubsection{Empirical Analysis of Influencing Factors}

In this paper, regression calculation of Tobit model in Equation 4 is carried out using EVIEWS 6.0 software, and the results shown in Table 5 are obtained.

Table 5: Tobit model regression results

\begin{tabular}{|c|c|c|c|c|}
\hline & Coefficient & $\begin{array}{c}\text { Standard } \\
\text { deviation }\end{array}$ & Z value & $\begin{array}{c}\text { Significance } \\
\text { level }\end{array}$ \\
\hline GDP & 0.000198 & 0.000339 & 0.79 & $0.000^{* *}$ \\
\hline M & 0.168272 & 0.138242 & 1.29 & $0.015^{* *}$ \\
\hline Gov & -0.41753 & 0.683367 & -0.21 & $0.612^{* *}$ \\
\hline IS & 0.026731 & 3.992653 & 0.78 & $0.003^{* *}$ \\
\hline cons & 0.21712 & 1.483725 & 0.35 & $0.001^{* *}$ \\
\hline
\end{tabular}

Note: ** means significance at $5 \%$ confidence level

It can be known from Table 5 that:

(1) The economic development level in Henan Province has a positive impact on logistics efficiency. The impact coefficient of the two is 0.000198 , indicating a certain degree of correlation. It is mainly because the 
rise of economic development level leads to increased input in logistics industry infrastructure, increased freight volume or turnover, which further improves logistics efficiency.

(2) Industrial structure in Henan Province has a positive impact on logistics efficiency with a correlation coefficient of 0.026731 . The high correlation indicates that industrial structure is an important factor influencing logistics efficiency. Rational adjustment of industrial structure in Henan Province can bring increased logistics efficiency to a certain extent, which is closely related to the development of tertiary industry (logistics industry) and the secondary industry. Transportation of industrial products is also an important source of income for the logistics industry. Rational adjustment of various industries ultimately leads to increased logistics efficiency.

(3) The effect of government intervention in Henan Province on logistics efficiency is insignificant, which is negatively correlated at 5\% confidence level, indicating that the role of government intervention in improving logistics efficiency is not obvious.

(4) Marketization degree in Henan Province is positively correlated with logistics efficiency with an impact coefficient of 0.138242 . This indicates that one unit improvement of marketization in Henan Province has led to a corresponding 0.138242 units of increase in logistics industry efficiency. Conversely, logistics industry efficiency is not high in some years in Henan, which is because marketization degree is not high enough, and then the high share of state- transportation enterprises has led to inactive market, thereby low logistics industry efficiency.

\section{CONCLUSIONS}

Based on the data of logistics industry in Henan Province from 2004 to 2015, this paper uses DEA model and Tobit regression model to calculate and analyze the logistics efficiency of Henan Province and its influencing factors. The conclusions are as follows:

(1) According to the model calculation, of the 12 decision-making units formed in 2004-2015, 9 years (decision-making unit) show effective DEA, and only efficiency in 2005, 2006 and 2010 is not optimal. In terms of the average of efficiency value, Henan logistics industry as a whole is at a relatively high development level. However, in some years, it is necessary to reduce the input of fixed assets to achieve the best level of resource allocation and scale.

(2) Based on the Tobit regression model calculation, there is no direct relation between government intervention and logistics efficiency. However, economic development level, industrial structure characteristic and marketization level have a strong correlation with logistics efficiency in Henan Province.

Therefore, under the circumstances that logistics resources are limited and logistics activities are increasingly dependent on the market and industrial structure, Henan Province should scientifically plan and rationally allocate and use logistics resources in implementation of "One Belt, One Road" strategy to achieve the best input and output, improve the overall efficiency and level of logistics; vigorously develop local economy from the perspective of system coordination, realize coordination among logistics enterprises, logistics industry coordination, as well as inter-industry coordination and regional coordination.

\section{REFERENCES}

[1] A Hamdan, KJ Rogers.Evaluating The Efficiency of 3PL Logistics Operations [J]. International Journal of Production Economics, 2015, 113 (1): 235-244.

[2] Binglian Liu, Yongze Yu. An Empirical Analysis on the Regional Disparity of Efficiency and Factor in China's Logistics--Based on DEA and Tobit Model[J]. China Business and Market,2010,24(09):18-21.

[3] Ganesh Vaidyanathan.A Framework for evaluating thirdparty logistics [J]. Communication of the ACM, 2005, 48 (1): 89-94.

[4] Jianqin Zhang. Empirical Study on Evaluation of Logistics Efficiency of Provinces of China Based on DEA. Logistics Technology,2013,32(09):359-361+368.

[5] Jingyi Zhang, Jingcheng Zhang. Comprehensive Research on Logistics Efficiency in China Based on Three-stage DEA Model [J]. Management World, 2016, (08):178-179.

[6] Kui Meng. Logistics efficiency evaluation of six provinces in central China based on three-stage DEA method [J]. Statistics \& Decision, 2014, (02):57-60.

[7] Xiaobing Le, Ying Wang. Logistics Efficiency Evaluation for Guangxi Based on DEA Model [J]. Science and Technology Management Research, 2014,34(05):54-57.

[8] Xueqing Zhang. Analysis of Regional Logistics Coordination Development in "One Belt, One Road" [J]. Statistics and Decision, 2016, (08):108-110.

[9] Zuchang Zhong. Research on the Efficiency of Logistics Industry in China Based on Three-stage DEA Model [J]. Journal of Finance and Economics, 2010,36(09):80-90.

[10] Zhaoda Lian, Detong Cheng. Logistics Efficiency Analysis of Key Provinces of “One Belt, One Road” Based on DEA Model [J]. Journal of Commercial Economics, 2017, (04):80-82.

[11] Zhanxin Ma.2016. Data Envelopment Analysis Models and Methods [M]. Beijing: Science Press 